\title{
THE ROLE OF CIREBON WOMEN ULAMA IN COUNTERING RELIGIOUS RADICALISM
}

\author{
Septi Gumiandari \\ IAIN Syekh Nurjati Cirebon \\ septigumiandari@gmail.com \\ Ilman Nafi'a \\ IAIN Syekh Nurjati Cirebon \\ Ilman.crb72@gmail.com
}

\begin{abstract}
The trend in terrorist acts nowadays is using women as perpetrators with a feminine approach. To respond to the condition, the figure of the Cirebon women ulama takes a very significant role. When women could be recruited as terrorists, it should be easier too to get them back to become agents of peace. This study originally attempts to describe the experiences and efforts of Cirebon women ulama in the process of socio-religious transformation in the Cirebon society towards a better direction, namely counteracting religious-based intolerance in Cirebon. This study was conducted through a descriptive qualitative method with a phenomenology approach. Primary data were obtained through documentation study, interviews, and direct observations with Cirebon women activists from various community organizations and non-governmental organizations. The results showed that there are several strategies used by Cirebon women ulama in countering religious radicalism such as (1) developing religious literacy among Cirebon society; (2) shifting communication patterns from monolog to
\end{abstract}


dialog; (3) reviewing curriculum and the process of learning; (4) living-in with other religious communities and beliefs, and (5) establishing institutional networking.

Keywords: Religious radicalism, the role, Cirebon women ulama.

\section{A. Introduction}

Religious intolerance acts are increasingly troublesome in Cirebon, West Java, Indonesia. People are easily ignited by their emotions when facing new and different religious understandings. Cirebon society seems to be easily carried away by issues and provocations especially related to religion and religiosity. They are easy to judge and claim heresy for anyone who is considered different from their worship activities. Differences in beliefs and ways of worship are responded with resistance and even violence. Religious minority groups often become the butt of intolerance. Marginal and minority communities are often alienated from social life.

From the results of preliminary research, the data showed that religious-based intolerance in Cirebon is caused by the widespread practice of spreading hatred in society towards certain religious groups, besides because there is not much space for dialogue between different communities (Rais, 2014). Religious minority groups often become targets of acts of hate speech which result in violence, discrimination, and hostility such as cases of hate speech against Ahmadiyah who get attacked and even expulsion of Ahmadiyah members from Cirebon. 
The above reality is reinforced by Azyumardi Azra's statement on Radar Cirebon, that Cirebon is an area that is vulnerable to the emergence of religious radicalism (Azra, 2014). According to him, as a region that is quite high in transition and urbanization, Cirebon is a potential area that became the basis of the development of radical Islam. This departs from the Psychology of radical Islamic networks in Indonesia which generally targets several regions that have their characteristics. In addition to conflict or post-conflict areas, the radical Islamic network targets people living in regions that are undergoing transition such as the people living in Cirebon.

The prediction revealed by Azra above shows the truth. Departing from the fears of the people of Cirebon about the presence of deviant religious understanding, the realm of religion in Cirebon in the last ten years was enlivened by the re-emergence of pros and cons about the heresy and whether a religious community existed in the community. Communities who have their religious ways that are different from society, in general, accept labels as heretical because they deviate from mainstream belief so they are not allowed to live in Cirebon. From this, religious radicalism began to gain momentum in Cirebon.

Ironically, the new trend in terrorism makes women as perpetrators. If previously the acts of terror had a masculine face and used a patriarchal approach, but nowadays terrorist acts utilize women as perpetrators and with a feminine approach. Even though women are perpetrators, they are essentially victims. Victims of their ignorance then used by those who have a systematic plan for acts of terrorism. Some 
factors are suspected as the reasons why women are involved in terrorism. Among them, the factors of association and friendship, feelings of alienation and exclusion, feelings of frustration and revenge, but the factor of radical ideology is the keyword when they are already in a terrorist group.

Some studies revealed that the women were recruited in the network. They were indoctrinated at all times with radical Islamic views. They were crammed with oppressed Islamic narratives, about the romanticism of the glory of Islam during the khilafah, about the obligation to establish a khilafah state that will free them from injustice and poverty, about the importance of carrying out jihad to eradicate injustice by infidels. They were also indoctrinated with stories of brave women in Islamic history and their obligation to uphold Islamic law and the importance of abolishing democracy and Pancasila state which they dubbed as thaghut (enemies of Islam) and believed that killing infidels (non-Muslims) is obligatory (Wulandari, 2019).

From the above explanation, it is clear, that the main motivation of women involved in this movement is theological. This is where the figure of the Cirebon women ulama gained its momentum. To respond to this condition, Cirebon women ulama from various parts of the world gathered in a series of Congress of Indonesian Women Ulama (KUPI) in 2017 in Cirebon, West Java, Indonesia. Around 1.200 participants from all over the archipelago and 15 countries from the world gathered to formulate and reaffirm the role of women ulama in collective action to respond to social and religious developments in society. The purpose of this forum is of course to help the role that has not been touched by kyai or 
the government, which is expected to be tackled neatly in a beautiful frame by women ulama, namely to restore friendly Islam, build a tolerant society frame and stem the swiftness of terrorism.

Through the above activities, it appears that women can be agents of disengagement. In other words, if they could be recruited as terrorists it should be easier to get them to become agents of peace. Because of that, a comprehensive strategy and a gentle or humane approach are needed but applies to those involved in the terrorism movement. Approaches that rely solely on militaristic power with the principle of security must be reviewed. Terrorist women's groups need to be given human touches and be given a place in mainstream social interaction. A campaign that constantly corners them without considering a human touch will only make them apparent death. Yet behind that, they continue to operate underground to rearrange their secret cells which one day rekindle the fire and the spirit of jihad which often leads to an explosion of terrorism.

The Cirebon women ulama movement above is in line with the statements of Ocktaviana at all. (2014) who saw that women have the potential to conduct peace activities. Women are far more advanced than men in insisting on the presence of basic human qualities. Women are more dedicated to peace and are against war and pay more attention to violence against children, and are so moved to what is called the Pall of Violence. This statement was also reinforced by studies conducted by Yustisia, I. R. (2016) who found that when women have the opportunity and political involvement, there is little chance of war. Based on this thought, this research was proposed. This 
study tries to explore the experiences and strategies used by Cirebon women ulama in countering religious radicalism.

Some previous studies are relevant to this research such as research conducted by Mahmood (2019). One of her researches about "Negating Stereotypes: Women, Gender, and Terrorism in Indonesia and Pakistan" found that terrorist groups have evolved in their recruitment methods, strategies, and target audiences. In both Indonesia and Pakistan, terrorist groups actively recruit women into a wide variety of roles. In other words, they have moved away from a narrow, static, and non-violent jihad to a broader, more fluid, and violent conception of jihad for women. States and policymakers need to evolve accordingly and account for the differing key roles women assume within these groups. The gendered presumption that women are 'naturally' non-violent, or agents of peace and are coerced by male-counterparts to engage in violence has acted as an impediment towards effective policy responses to identify and mitigate the threat from female terrorists. While Rosyid (2018) in his study "Perempuan dalam Jaringan Radikalisme Vis a Vis Terorisme Global" showed that women's involvement in the terrorist movement has been identified since the 1970s, where women became bombers after being brainwashed by male terrorists. Factors that led to the involvement of women in the global terrorism network, namely: 1) as an escape because of the discriminatory treatment that befell them; 2) reasons for concern over the inequalities suffered by the global Muslim community; 3) narrow religious awareness so that by becoming terrorists they feel they have the same social position as male terrorists in jihad; 4) psychologically 
unstable because of problems, and they surf on social media, so they are vulnerable to being trapped as terrorists and; 5) women whose husbands become terrorists are also involved as terrorists. The strategy carried out by terrorist groups in conquering women is by marrying them, even marrying them through social media that is legalized and/or legalized, so that according to the husband's wishes.

On the other hand, Yesa (2000) in her research on "Women's experiences in the fight for peace in conflict areas: research on women members of the caring women's movement in Ambon" showed that the biggest motivation or reason for women to be involved in peace efforts, although most of them is a victim of the conflict, stemming solely from women's concern for the future of their children. This has made them able to transform their existence as victims of conflict into peace actors. While Sumbulah (2019) in her study on two civil society women activist groups, namely Fatayat NU and Family Welfare Empowerment (PKK), who had concerns about empowering women through strengthening family resilience that, found the role of these activists in preventing radicalism can be categorized into two categories. Prevention of radicalism for families who have not been exposed to radicalism is done by strengthening family resilience through economic, health, education, socio-religious activities, and an increased understanding of radicalism, i.e. by detecting and avoiding radical ideologies. For high-risk families or those who have been exposed to radicalism, these civil society organizations provide intensive assistance through social-based strengthening and trauma healing. Assistance to children of former terrorists is carried out by these 
organizations to ensure the fulfillment of children's rights as guaranteed by law. These organizations also collaborate with the government and NGOs to increase the effectiveness in preventing family-based radicalism. The paper concludes that the role of women, families, and communities is strategic in creating a harmonious family atmosphere and preventing family members from being exposed to radicalism.

Moreover, Muthohirin (2015) discussed Islamic radicalism and its movements on Social Media. This research focuses on Islamic radicalism groups incorporated in the Indonesian Hizb ut-Tahrir (HTI) organization, Harakah Tarbiyah, and the Salafi Jamaah. The findings of this study indicate that the Islamic radicalism movement has emerged in virtual networks. Facebook, YouTube, Twitter, Tumbler, and free application services like WhatsApp. The digital media has become a space for new ways to do propaganda, recruitment, training, planning, and invitation to establish the Islamic Khilafah. The current strategy that they do has influenced the way of thinking of Muslim communities and targeting young people as the majority of citizens in social networks (netizens).

Wulandari (2019) about "Online Radicalization: Imagination and Expression of salafi-jihadi Muslimah in Surakarta." Her research aims to examine the imagination of "true Muslims" for young Muslim women salafi-jihadi activists in Surakarta. Based on qualitative research, the results showed that the posts uploaded in social media accounts illustrate the expression of the jihadist' ideology. The author argues that the imagination expressed through online activities is the result of negotiations both externally and internally. The 
purpose of external negotiations is the involvement of young Muslim women in the salafi-jihadi community. While internal negotiations, namely their willingness to accept the doctrine of jihadists while joining the community. Young Muslim women have a stake in the online radicalization process. This research contributes to the discussion of the proliferation of radical ideas in online space in Indonesia.

Keller (2016: 261) wrote through another perspective regarding the use of the internet for the women's movement, namely the internet as a place where women's voices, especially teenagers, can be accommodated and heard. Research reviewed by Keller revealed that adolescent girls do not have their own space to express themselves. Their voices are not heard in the political sphere, for example in elections, or are not seen when there is an action at the town hall (Keller, 2016: 261-262). The virtual world is a place where women are freer in politics without feeling marginalized or feeling that their voices will be silenced. Keller writes that through blogging on the internet, young women can participate in voicing their opinions and developing contemporary feminism movements.

The various studies and writings above can be used as a comparison for this research, but they are not used as a concrete reference, because different study areas are assumed to have different patterns and colors. None of the studies above were specifically focused on Cirebon women ulama and religious radicalism. Therefore, this study originally attempts to describe the experiences and efforts of Cirebon women ulama in the process of socio-religious transformation in the Cirebon society towards a better direction, namely 
counteracting religious-based intolerance in Cirebon. This is very important research because besides as a lesson learned for the struggle of Indonesian women ulama in the future, it is also an effort to document the portrait of Indonesian women's agencies in their participation in spreading peace in increasingly thickening religious-based acts of violence in various parts of the world.

This study used a descriptive qualitative method (Kreuger \& Neuman, 2006) with the phenomenology approach (Giorgi, 2009). Primary data obtained through documentation study, interviews, and direct observation with informants. Interviews were conducted with Cirebon women activists from various community organizations and nongovernmental organizations that have diverse backgrounds. Secondary data obtained through the scientific literature, writing, documentation, and internet-based information that can support primary data. Data analysis techniques used in this study include interview transcripts, data reduction, data interpretation, and triangulation (Miles, 1992). From the results of data analysis then conclusions are drawn.

\section{B. Map of Religious-Based Conflict and Radicalism in Cirebon}

The term 'radical' actually has various meanings. It can be interpreted as fundamental, essential, reformist, and open. Radicals can also be understood as extreme, militant, partial, and hard in fighting for something. 'Ism' which is attached to the radical term refers more to an extreme and excessive understanding to exceed the limits (Hassan, 2015). 
The word 'radical' is often connoted in a negative context. Radical usually leads to an understanding of the attitudes and views that are militant, strong, and hard in fighting for the aspirations of his opinions. Negative meaning is often directed and connoted to a term called radicalism. The most common understanding of radicalism leads to a political movement that makes religion an ideological basis. The strength of its militancy lies in a tendency to establish religious doctrine as a universal principle in regulating the existing order. It means that radicalism is interpreted as a certain understanding or flow that is so militant and extreme in politics. Radical groups want a great change and renewal of the social and political system based on religious principles. This group often uses violent methods to drastically change the system that has been considered far from religious values.

As a religious-based political movement, radical groups often want the formation of a state based on sharia principles. They believe that only with this system, justice and independence can be easily carried out amid the chaos of injustice, social inequality, and rampant corruption. They are so convinced that the khilafah is the only way to arrive at perfect justice (Fealy, 2004).

In a pluralistic society like Cirebon, religion can have two faces. Religion can be a unifying factor and at the same time triggering social conflict. This is in line with the statement of Bahtiar Effendy (in Putra, 2019) who sees that the presence of religion is always accompanied by "two faces". On the one hand, religion has an identity that is "exclusive", and "primordial". On the other hand, religion also has an identity that is "inclusive", "universalist", and "transcending". 
The antagonistic potential of this religion has been one of the main concerns of religious activists and thinkers.

The dualism of the face of religion was born due to the diverse meanings of the existence of a religion. Will religion be placed in its position as the purpose of life or only as an instrument to maintain humanity and achieve human happiness? For groups who see religion as an instrument to achieve happiness, it will give birth to a view that religion puts the problem of humanity at a high position and therefore religion exists as a "servant" for humanity. Therefore, every act that humiliates and destroys human values and existence is the same as insulting religion itself. As for groups who view religion as a goal, they position human life for religion. Therefore, for the sake of religion, the value and existence of humanity can be sacrificed whenever needed, by carrying symbols and raising the banner of religion from the "attack" of its enemies. The tragedy of the Bali bombing, Marriot, and various acts of terror in the Indonesian hemisphere some time ago, became its legitimacy for the validity of this view.

In the context of religious behavior, Cirebon society has always been known as a religious and plural society. The word "Kota Wali" is one indication that Cirebon is a city of students that has more than 500 Islamic boarding schools and other Islamic education. In almost every village in the Cirebon region, there are Islamic educational institutions, such as the Al-Qur'an Education Park (TPA), Majlis Ta'lim, and others. Besides that, Cirebon society is also known to be plural because it consists of various tribes and nations, such as Javanese, Sundanese, Malay, Buginese, and Madurese. Its people are a combination of various countries, such as China, 
India, and Arabia. In the past, religious minority groups, such as Christians, Catholics, even Ahmadis, Shiites, or other religious sects, could coexist with the majority religious groups. The minority religious group can live in peace and freedom to practice their religion or belief without fear of intimidation or attack

Cirebon not only illustrates an area with multireligious, ethnic, and regional cultural and historical heritage but also the corners where the cultural exchange takes place, which allows for an increase in knowledge, knowledge, and cultural acculturation. Indicators of cultural acculturation can be seen through (1) the building of its palaces which have elements of Indian, Javanese, Dutch, Chinese, as well as Arabic; (2) the use of tiled palace roofs is a Hindu influence, but the white wall, then the hall filled with chairs lined up and facing each other is a cultural heritage of Europe; (3) Ceramic porcelain on the palace walls is Chinese influence, but various calligraphy, also the existence of a mosque around the palace is a representation of Islam. Likewise, (4) places of worship, such as churches and temples of compassion that have been around 700 years old, still perched in Cirebon to show cultural acculturation that has indeed been manifested in Cirebon. Even about spirituality, the Cirebon palace is often used as a reflection of a gentle and tolerant Islam.

Over time, the friendly and tolerant attitude of the people of Cirebon seems to fade, even now a new popular image of Cirebon has emerged which is often attached to the actions and behaviors of intolerance. Hateprovoking practices of hatred based on religion appear to be increasingly mushrooming, leading to the presence of 
violence, discrimination, and hostility so that individuals or groups from religious minorities are often targeted for hatred based on religion. Various acts of religious-based intolerance took place in Cirebon (Rais, 2014). Some can be mentioned here, such as:

First, cases of violence that occurred in the HDH (Hidup Di Balik Hidup) community in Cirebon. HDH is a religious community or majlis ta'lim who entered Cirebon Regency in 2002, precisely in the village of Sigong, Lemahabang District, Cirebon Regency. HDH Jama'ah in Cirebon district there are around 84 people. The Majlis Ta'lim was brought by someone named Mujoni Abdullah (64 years), a Bekasi resident from East Java. Since its inception in Cirebon in 2002, HDH has been able to carry out study sessions safely and is not considered an activity that is troubling the community. However, after Indonesia was shocked by the rise of misguided labels addressed to the Ahmadiyah and other communities around 2005 reinforced by the MUI reincarnation in 2007, at the end of 2007, ripples of heresy also began to be rolled out and addressed to the HDH community. Not only the people who mislead this community but the Ulama Council of Indonesia (MUI) Cirebon District also issued a fatwa and stated that the HDH majlis ta'lim was a heresy which was then followed up by the Cirebon resort police by questioning some of the $\mathrm{HDH}$ followers and even detained some of them for three days.

Second, violence in the name of subsequent religion befalls Ahmadiyah communities in Cirebon and the neighboring regions such as Kuningan and Majalengka. This event caught the attention of many parties, because it happened not only between religious groups butalso involved 
the government. Because both the central government through the Ministry of Religion, the minister of the interior, and the attorney general issued a decree which prohibits the activities of the Ahmadiyah Indonesian congregation (JAI) which is Qodian. The decree to ban Ahmadiyah activities was also issued by several regional heads such as regents/ mayors or governors. Violence in the name of religion in other Ahmadiyah communities also befell the Millah Ibrahim group led by Djubaedi Djawahir, a teacher from Kuningan, who is located on Jl. Kemuning Cirebon City. On December 20,2009 , this group was attacked by other religious groups, because so far it has been seen as spreading religious ideas that are different from the generality of Muslims. So the Millah Ibrahim group is considered a heretical group. After being attacked and declared heretical, this community then disbanded, and until now no more activities have been heard.

Third, the most horrendous of the people of Cirebon is the event that befell Ahmad Tanthowi, the leader of the "Surga Adn" community. Because he was also deemed to have deviated and spread heresy, Ahmad Tanthowi had to sit on a court seat in the Sumber Cirebon court for days. Previously, Ahmad Tanthowi also had to accept violence from people and certain groups who attacked his house, until finally he was forced to sit in a chair in Cirebon Source Court for days. That is because the presence of Ahmad Tanthowi is considered disturbing the public. Because of that, he was later secured by the police and prosecuted by the prosecutor with article 165a regarding blasphemy, article 289 about molestation, and article 335 of the Criminal Code concerning unpleasant acts. 
Fourth, violence also afflicts the Christian community. In the last ten years, this community is often under pressure and even violence in various forms, such as the prohibition of worship in places other than churches (such as school buildings, hotels, meeting halls, and other places), intimidation against churches that do not have completeness documents, prohibitions on carrying out social activities and so forth. Even the process of establishing a place of worship was not escaped from intimidation both to the committee and to the people who agreed to the construction of the church as mandated in the joint regulation of the minister of religion and the minister of the interior number 9 and 8 of 2006. As mentioned in article 14 letters ( $a$ and b). This regulation specifically requires the existence of 90 lists of names of worshipers and 60 local communities' supports. At the field level, these special conditions are utilized by irresponsible persons, using them for their personal and group interests. This reality makes Christians pessimistic that the new church can be built in Cirebon.

Fifth, it not only affects different religious groups, even at the internal level of Muslims, violence between religious groups also occurs. Differences in religious understanding, it seems still a major problem so that the seeds of violence emerge. Besides, contestation between religious groups also became part of the emergence of violence. Only because of carrying out deba'an training activities (reading nadham barzanji) accompanied by tambourines, a group of children in the Kapetak area, Cirebon, had to receive terror several times. For the umpteenth time, the perpetrators were then reported to the police and finally thrown into prison for 
doing damage to the musholla which became a children's training ground.

The most phenomenal internal violence of Islam is the two bomb experiences in Cirebon: (1) the bomb at the Sang Cipta Rasa Kasepuhan mosque (which failed to explode) and (2) the suicide bombing at the Mapolresta ad-dzikra mosque in Cirebon on April 15, 2011 (Rais, 2014). Both are strong evidence that plurality awareness in this city must be maintained so that similar cases and violence and conflicts based on religion are no longer repeated. In the city of Cirebon, there was also a case of banning the use of headscarves in a private school. Besides, The RAPERDA (draft of Regional Government Regulations) on religious education was also rejected by leaders of non-Muslim religions in the Cirebon City DPRD. Lobbies and other advocacy efforts to thwart so that religious education is not regulated in the PERDA (Regional Government Regulations) failed to be approved by the DPRD. Not to mention, the action of rejection of the Ahmad Dani concert by certain Islamic mass organizations, as well as violent actions to disperse or expel minority groups in Cirebon Regency.

Some of the cases of religious-based violence above show a fact that some mass organizations and some people of Cirebon have made violence as part of their activities in responding to differences. This condition should ideally have opened collective awareness of the importance of turning the fact of religious-based intolerance into a fact of tolerance. The transformation from intolerance to tolerance is one of the maximum measures of the civilization and civilization of a society. The more tolerant society is, the automatic level 
of public civilization and its civilization will automatically achieve maximum results. Therefore, tolerance is a value and attitude that must be developed in and for all citizens.

\section{Cirebon Women Ulama as Narrative Agents in Counteracting Religious Intolerance}

Women ulama consists of two words: "ulama" and "women". The word "ulama" is a plural form of the word 'alim which means someone who knows or is very knowledgeable, without limiting certain scientific disciplines. It is also not limited to a certain gender. "Ulama" is often attached to religious leaders who can understand the sources of Islam well, behave nobly, and guide people in their daily lives (Fayumi, 2017).

The Qur'an mentions the word 'alim with singular form 13 times $(9: 105,13: 9,32: 6,33: 92,34: 3,35: 38,39: 46,59: 22$ , 62: 8, 18:64, and 72:26). Everything is about the nature of Allah, the All-knowing in all things, both visible and invisible. While the word 'ulama in plural form is only mentioned once in Surah Fathir (35:28). This verse talks about the basic character of ulama who should have high integrity because they are only afraid of Allah. Another word that still has the same root is "ulul 'ilmi" (the man of knowledge), found in the surah al-Imran (3:18), regarding the main task of the ulama to uphold justice. The Qur'an also mentions several other words that have the same meaning as ulul 'ilmi, namely ulul abshaar (QS al-Hasyr, 59: 2), ulil al-albaab (QS Ali Imran, 3: 191), Ahludz dzikr (Surah al-Nahl, 16:43), and others.

Departing from the sources of the text above, the word "ulama" is a person of deep knowledge, who has fear of God 
(integrity), noble personality (akhlaaq kariimah), practice, deliver, uphold justice, and give benefit to the universe (rahmatan lil 'alamiin). While the word "women", according to the Congress of Indonesian Women Ulama (KUPI) in 2017, has two meanings: biological and ideological. According to the definition of the Indonesian Dictionary, women are the biological humans who have female genitals, can menstruate, become pregnant, give birth, and breastfeeding. Whereas ideologically, the meaning of "women" can mean perspectives, awareness, and partisanship movements for women to realize justice to men, both in family and social life.

These two meanings are used to distinguish the word "women ulama" from "ulama women". "Ulama women" are all people who are female who have the religious capacity, both those who have a perspective of gender justice and those who have not, while "women ulama" are all ulama, both males and females, who have and practice a perspective of gender justice. "Women ulama" work, intellectually and practically, to integrate the perspective of gender justice with Islamic sources in responding to the realities of life in the context of upholding fair and civilized humanity.

The meaning of "women ulama" implies a continuous process to affirm and ensure that the role of the ulama, with the knowledge they have, is to realize fair and civilized humanity. This meaningfulness entails involving women as subjects and beneficiaries in all religious activities. In this long process, the identification and appreciation of ulama women from the early days of Islam to the present is a necessity to emphasize the existence and legitimacy of women ulama. 
In the KUPI's perspective, "women ulama" are people who have deep knowledge, both women and men, who have fear of God (integrity), noble personality (akhlaaq kariimah), uphold justice, and provide benefit to the universe (rahmatan lil 'alamiin). Fear of Allah SWT is not only for humanitarian matters in general but also in the affairs of women specifically. Not only in public affairs, but also in family matters. Likewise, the noble, uphold justice and provide benefits, not only in matters relating to men but also the same in matters relating to women. Thus, harmonious mutual relations between men and women can be bound, and without violence to realize the ideals of humanity that are just and civilized (Fayumi, 2017).

The term "agent" is used because the agent has a more flexible and broad role. The term agent was adopted from Durkheim's concept of a qualified actor (knowledge actor) who has a role in the reproduction of cultural meanings and norms (Fardon (ed), 1985:6). The concept of an agent rests on his ability to influence others with a variety of order of meaning and narration in the process of interaction that occurs (Fardon (ed), 1985:10). While Berman (1998:51) defines agency as the role of personal responsibility in discursive activities. This definition is taken from the opinion of Muhlhausler and Hare in Fill and Peter (2001) that agency as one aspect of subjectivities is based on the capacity of one's critical reflection on what is thought and done.

In this context, the term 'narrative agent' is used, because it has a closeness of meaning to the term 'narrative speaker/ teller' used by Berman (1998: 59-62). The 'narrative maker' is not used here because the agent does not always produce discourse, but it can simply convey and adopt the ideas and 
concepts of others, both conventionally established and new ones. Only a small number of narrative agents are narrative makers, most of them are distributors and disseminators of established ideas, both inside and outside their organizations. However, they have broad influence or reflect a dominant discourse, both because of the effective media used and because of their position as elite in the association. Agents represent narratives that reveal the discourse circulating in their institutions, what is believed and thought by followers of the organization about humanity, human rights, democracy, tolerance, and the issue of religious pluralism. They also represent the inclination and orientation of that thought or equivalent, as well as the contestation within it.

Based on the breadth of its influence on the institution, the Cirebon women ulama's narrative agent broadly and somewhat flexibly can be elaborated their role in sowing peace and religious tolerance in the following explanations:

\section{1) Developing Religious Literacy}

According to Purnomo (2001), one of the strategies, as well as the most important challenges of the life of religious pluralism to know each other is to develop religious literacy. What is meant by religious literacy is an open attitude towards and knowing the values in other religions. In short, religious literacy is an attitude of "literate other religions". With the "literacy of other religions", people can get to know each other, respect each other and respect each other, cooperate, develop and enrich the natural life of a true brotherhood among religious people, whatever their religion. 
The development of religious literacy is parallel with the world of education which seeks to eradicate illiteracy. When people are instructed to be literate, then they become able to write and read. Therefore, in addition to breaking down the situation of illiterate people, the community is also challenged to develop an attitude of religious literacy as a form of dismantling the situation of people who are "blind to other religions". Quality education leads humans to openly engage in religion, so in organizing education Indonesian children should be able to become "literate in other religions", because if reading and writing lessons in schools can save the nation from illiteracy, religious education can lead Indonesians not to become "blind to other religions", so that they tend to be closed-fanatical, as well as easily despised, pitted and contested (Purnomo, 2001).

This religious literacy is spread by Fatayat NU, Aisyiyah, and Fahmina Institut through a series of activities, both formal and informal, through various media; print (newsletters, community radio broadcasts, or blogs). Formal activities are carried out through lectures, preaching in various educational institutions including boarding schools, campuses, and schools. While informal activities are carried out through seminars, anti-hate speech demonstrations, messages of peace in reflection on religious holidays, monthly visits to various places of worship.

Besides that, to cultivate a culture of peace, the Fahmina Institute is the most progressive organization in this regard. This institution created a religious literacy 
training called SETAMAN (Sekolah Cinta Perdamaian). This training is programmed for young people who are given material, reinforcement, and techniques to facilitate forums on issues of equality, human rights, pluralism, and religious tolerance. After the training, they will be deployed to 5 districts and cities of Cirebon to become facilitators in further preaching the importance of religious literacy.

\section{2) Shifting Communication Patterns From Monolog to Dialog}

In a holistic paradigm, Purnomo (2001) emphasized that religious literacy will provide space for the creation of dialogue and cooperation between religious communities. In dialogue and cooperation between religious communities, every faithful person can honestly and openly offer truth, goodness, beauty, and peace to one another, not to recruit and influence each other; but to deepen the appreciation of his faith and religion for the sake of prosperity and true brotherhood.

Shifting communication patterns from monologue to dialogue is one solution to reduce misunderstanding between religious communities and society. Through dialogue, we will get an understanding that conflicts often occur not because of the existence of their religion, but rather because of the politicization of religion and the economy. In this context, religious leaders must explain the actual events by showing evidence that the conflict is not religious. 
Religious leaders must be active to always promote the importance of mutual understanding between people, respect each other, and refrain from being easily provoked. Intensive dialogue is expected to create true friendship, the friendship that is not merely a discourse. Dialogue between religious communities should not only be at the level of religious elites but also the level of ordinary people.

From this understanding, various communities of different religions can respect other religious traditions as their owners (face other religious traditions as the owner). Where so far the understanding of other religions tends to be subjective, it is necessary to have effective mediation to build interfaith relations.

As a mediator to glue the silaturrahmi ties and presentadialogicalatmospherebetweenvarious religious communities, Fahmina Institute attended to create many forums such as "Respect and Dialogue" which they also called the abbreviation READY, PELITA (pemuda Lintas Iman), MB2 (melek bengi-bengi), and so forth. These various institutions are engaged in creating a space for dialogue between religious communities regularly with a predetermined time and theme. READY and PELITA consist of a group of young people from various religious beliefs such as young Catholics, Buddhist Patria, Hindus, Protestant Christians, Ahmadiyah, Syi'ah, Jews, and others. Likewise with MB2 as a forum for dialogue and discussion on issues of tolerance by the students which are usually held at night in various boarding schools. This is where Fahmina Institute conducts Capacity Building 
(CB), strengthening both in terms of its personnel and institutions.

From the intensive process of youth dialogue and creativity through these forums, various books and modules related to the issue of religious tolerance were produced by the Fahmina Institute as follows: (1) (1) Islam Toleran written by KH. Husein Muhammad; (2) Siar Anti Kebencian, edited by Faqihuddin AK; (3) Belajar Keagamaan; (4) Panduan HAM untuk SATPOL and others. Besides books and modules, there were also videos of tolerance, gravity, screen printing, and games about tolerance.

\section{3) Reviewing Curriculum and the Process of Learning}

The best way to carry out the de-radicalization of religion through educational institutions is the curriculum review movement at various levels of education to develop the knowledge, attitudes, and actions of the anti-radicalization of this religion. Religious education in schools has so far been more filled with fiqh material, especially fiqh of worship. Starting from elementary to high school and even university, what is taught is the issue of thaharah to the matter of body management. Especially if what is obtained is only at the level of knowledge of worship and not an experience of worship.

When the terrorist movement carries offensive jihad in understanding it, for example through suicide bombing, terror with violence, and so on, then surely it must be taught about the meaning of jihad adequately. A moderate understanding of jihad is to work hard to 
achieve an excellent goal especially for the benefit of the people so that jihad should not be removed from the teachings because the connotations are misinterpreted. However, there must be adequate efforts to provide adequate explanations as well. Of course, there must also be a teacher or lecturer who can explain the meaning of jihad which gives benefits for the universe, rahmatan lil 'alamien. Therefore, educators also need to be professionally selected so that they do not teach Islam or any religion by the radical conception. If that is the case, then, on the contrary, educators may even become agents for the development of religious radicalism.

Apart from the content of the material, the learning process also must get serious attention. Through practical learning in the classroom, tolerant attitudes are not only cognitively absorbed by students, but can be felt affective, and finally psychomotor can be implemented. Another part of practical education is the delivery method for ongoing education. There are several learning methods such as discussion, role-playing, tutorials, and class visits or field trips related to local cultural studies. For example, when an educator teaches morality, the teacher can use the role-play method and discussion conducted by students. Students are asked to play the role of religious leaders who try to respect other people of different religions, a teacher appoints several students to play drama. The second case in learning practice is a discussion related to how Muslims view Christians and vice versa. 


\section{4) Living-in with Other Religious Communities and} Beliefs

To support the efforts of understanding the clerics more clearly in understanding other religions, the Fahmina Institute, as a representative of organizations supporting the existence of Cirebon women ulama, has held live-in with other communities program, namely in the Ahmadiyyah community and the Sundawiwitan Cigugur community. The positive value of this livein process is the change in perspective towards other traditions, from a subjective perspective to an objective perspective. For example, Christian participants felt surprised because they were greeted with a very friendly. Even before leaving, they all felt nervous, afraid of not getting a good reception, because as we all know, a lot of negative stigmas are addressed in several Muslim communities, including pesantren.

Through live-in activities, their views change. At least, they realize that Muslims can also be used as friends to share. Even though when they live in, they have to encounter a variety of strange atmosphere, it is not a significant problem for them compared to the spirit of brotherhood that they will develop in the future. The other main point is the emergence of an awareness of how to respect the traditions of other religions as the owners of traditions respect them.

\section{5) Establishing Institutional Networking}

Among the roles that are also effective in the framework of accelerating the dissemination of a 
culture of peace among the people of Cirebon is by establishing cooperation, consolidation, and building networks between institutions both internal and external (Rais, 2014). Internal networking is done by building networks between interfaith institutions. This activity is held in Cirebon for 3 (three) months. Whereas external networking is done by building consolidation with the police related to their duties and functions that are required to carry out security and may not be tendentious, human rights, and various issues of radicalism. Consolidation with various parties is important to do. When the empowerment programs are carried out partially and not integrated, they will be difficult to materialize, even if they are successful, they will be a long process.

In this context, Cirebon women ulama has collaborated with several institutions such as (1) Join in Jaringan Persaudaraan Sejati (JPS) that works to advocate for central government policies that do not favor religious freedom and diversity. In this context, the policy that advocates are the RUU kerukunan umat beragama (KUB); (2) Join in Jaringan Pemantauan Pluralisme, a network of pluralism monitoring to handle cases of violence in the name of religion. This network also monitors government policies that do not reflect alignments with cultural, ethnic and religious pluralities; (3) Facilitating the establishment of interfaith networks in the regencies and cities of Cirebon which are members of the Sabtuan Forum, since 2000 until now; (4) Facilitating the establishment of a network for monitoring and 
advocating for freedom of religion and belief (JAKER PAKB2) in West Java province in 2007.

\section{Conclusion}

This research reveals that various acts of religiousbased intolerance happened in Cirebon. Some of them are: First, cases of violence occurred in the HDH (Hidup Di Balik Hidup) community in Cirebon. Second, violence in the name of subsequent religion befalls Ahmadiyah communities in Kuningan, Cirebon, and Majalengka. Third, the most horrendous of the people of Cirebon is the event that befell Ahmad Tanthowi, the leader of the "Surga Adn" community. Fourth, violence also afflicts the Christian community. Fifth, it not only affected different religious groups, even at the internal level of Muslims, violence between religious groups also occurs. The most phenomenal internal violence of Islam was the two bomb experiences in Cirebon: (1) the bomb at the Sang Cipta Rasa Kasepuhan mosque (which failed to explode) and (2) the suicide bombing at the Mapolresta ad-dzikra mosque in Cirebon on April 15, 2011.

Responding to some acts of religious-based intolerance above, the figure of women ulama in Cirebon took a very significant role. As a narrative agent, they come forward with several strategies such as (1) developing religious literacy among Cirebon society; (2) shifting communication patterns from monolog to dialog; (3) reviewing curriculum and the process of learning; (4) Living-in with other religious communities and beliefs, and (5) establish institutional networking 
This study is very important because in addition to be lessons learned for the future of women struggle, it is also an effort to document the portrait of Cirebon women ulama in their participation in spreading peace in the midst of intensifying religious-based violence in Cirebon. Besides, this research can academically be a very significant effort in terms of completing scientific treasury in the study of gender, religious and political sociology, where this study is expected to be used as an input for society in general and policymakers in particular, in improving women's access and control as an embodiment of justice and gender equality in politics for the creation of a tolerant and humanist civilization.

\section{REFERENCES}

Azra, A. (2014). "Memahami Hakikat Radikalisme” in Radar Cirebon, 15 April 2014.

Berman, L., \& Berman, L. L. A. (1998). Speaking through the Silence: Narratives, social conventions, and power in Java. Oxford University Press on Demand.

Dobson, Amy Shields. (2015). Postfeminist Digital Cultures: Femininity, Social Media, and Self-Representation. New York: Palgrave MacMillan.

Fardon, R. (1985). Power and knowledge: anthropological and sociological approaches. Scottish Academic Press.

Fayumi, B. (2017). Peran Ulama Perempuan dalam meneguhkan Nilai Keislaman, Kebangsaan dan Kemanusiaan in Indonesian Women's Ulama Congress (KUPI), Cirebon, West Java, Indonesia.

Fealy, G. (2004). Islamic radicalism in Indonesia: The faltering revival?. Southeast Asian Affairs, 2004(1), 104-121. 
Fill, A. \& Muhlhaausler, P. (2001). The Ecolinguistics Reader Language, Ecology, and Environment. London: Continuum.

Giorgi, A. (2009). The descriptive phenomenological method in psychology: A modified Husserlian approach. Duquesne University Press.

Hassan, G. S. (2015). Radical Islam/Islamic Radicalism: Towards a theoretical framing. Canadian Journal of Sociology, 12, 1-4.

Keller, J. (2016). “Making Activism Accessible: Exploring Girl’s Blogs as Sites of Contemporary Feminist Activism" in the book Girlhood and the Politics of Place (Ed. Claudia Mitchell and Carrie Rentschler).

Kreuger, L., \& Neuman, W. L. (2006). Social work research methods: qualitative and quantitative approaches: with Research Navigator. Pearson/Allyn and Bacon.

Mahmood, S. (2019). "Negating Stereotypes: Women, Gender, and Terrorism in Indonesia and Pakistan" in Perspectives on the Future of Women, Gender \& Violent Extremism. Washington, DC: The George Washington University, 11-20.

Marcoes, L. (2010). Oposisi Maya. Yogyakarta: Insist Press.

Miles, M. (1992). Analisis data kualitatif. Jakarta: UI-Press.

Moleong, L. J. (2002). Metodologi Penelitian Kualitatif. Bandung: Remaja Rosdakarya.

Muthohirin, N. (2015). "Radikalisme Islam dan Pergerakannya di Media Sosial. Afkaruna, 11(2), 240-260.

Ocktaviana, S., Santoso, W. M., \& Purwoko, D. (2014). PeranPeran Perempuan Di Wilayah Konflik: Antara Korban, Penyintas, Dan Agen Perdamaian. Jurnal Masyarakat dan Budaya, 16(3), 383-398. 
Purnomo, A. B. (2001). Religious Literacy dan Tantangan Pluralisme Agama. Jumat, 9 November 2001, Kompas Cyber Media.

Putra, A. E. (2019). Tarik-Ulur Antara Radikalisme dan Multikulturalisme dalam Studi Agama di Abad Ke 21. AlAdyan: Jurnal Studi Lintas Agama, 14(1), 1-18.

Rais, M. et all. (2014). Membangun Kebersamaan dalam Keragaman; Potret dari Cirebon. Cirebon: Yayasan Fahmina.

Robinson, BA. (2001). Reacting to Religious Diversity: Religious Exclusivism, Pluralism, and Inclusivism. Look at http://www.gospelcom.net/

Rosyid, M. (2018). Perempuan dalam Jaringan Radikalisme vis a vis Terorisme Global. Muwazah. 10(2), 162-182.

Sumbulah, U. (2019). Preventing Radicalism by Family and Civil Society Organizations in Indonesia. Pertanika Journal of Social Science and Humanities, 27(1), 391403.

Wulandari, C. T. (2019). "Online Radicalization: Imagination and Expression of Salafi-Jihadi Muslimah in Surakarta," in AICIS Proceeding Conference.

Yesa, L. (2000). "Pengalaman perempuan dalam upaya memperjuangkan perdamaian di wilayah konflik: penelitian terhadap perempuan anggota gerakan perempuan peduli di Ambon." Tesis. Depok: UI. http:// lib.ui.ac.id/opac/ui/detail.jsp?id=95009\&lokasi=lokal

Yustisia, I. R. (2016). Potensi dan Peran Perempuan Dalam Gerakan Perdamaian. Proceeding AMIPEC, 2(2).

Zaenuri, A. (2019). "The Role of Social Media in Forming Religious Identity of Veiled Female Students in Higher Education: Study on Veiled Students Phenomena at College In Gorontalo" in AICIS Proceeding Conference. 